\title{
Pemberdayaan Masyarakat Kelurahan Trimulyo Semarang Melalui Program Gerbang Hebat
}

\author{
Mariana Kristiyanti \\ Universitas Maritim AMNI Semarang \\ mkristiyanti75@gmail.com
}

\begin{abstract}
The city of Semarang is currently improving to actualize the saying of 'Moving Together Building the City of Semarang to Be Better and Great' both physically and non-physically. One of them is through Gerbang Hebat program. It is an activity in reducing poverty and unemployment, improving public services, gender equality and improving education also health as stated in the Sapta program (Reducing poverty and unemployment, Handling Floods, Improving Infrastructures, Improving Public Services and Gender Equality). UNIMAR AMNI Semarang carried out community service activities at Trimulyo village to support the government of Semarang program. It is not only students/cadets and lecturers who carry out community service activities but also the surrounding community. They are very enthusiastic in participating in implementing various program activities carried out at Trimulyo village. The activity begins with planting mangrove trees, socializing healthy living in an unhealthy environment, training in cooking and tidying up the environment.The method of implementing the activities used is the method of observation, interviews and literature studies. The observation was held in Trimulyo village, sub-district of Genuk. The data collection was carried out through interview methods and as a reference for implementing community service activities was using the literature study method. With UNIMAR AMNI Semarang Gerbang Hebat program at Trimulyo village of Subdistrict Genuk hoped that it can improve the healthy lifestyles and increase the income of the Trimulyo village community.
\end{abstract}

Keywords: Empowerment, Trimulyo Village, Gerbang Hebat, Semarang City Goverment

\begin{abstract}
Abstrak: Kota Semarang saat ini tengah berbenah guna mewujudkan slogan 'Bergerak Bersama Membangun Kota Semarang Menjadi Lebih Baik dan Hebat' baik fisik maupun non fisik. Salah satunya adalah melalui program Gerbang Hebat Kota Semarang yang merupakan kegiatan dalam penanggulangan kemiskinan dan pengangguran, peningkatan pelayanan publik, kesetaraan gender serta peningkatan pendidikan dan kesehatan yang tertera dalam sapta program (Pengentasan kemiskinan dan Pengangguran, Penanganan Rob dan Banjir, Peningkatan Infrastruktur, Peningkatan Pelayanan Publik dan Kesetaraan gender). Guna mendukung program Pemerintah kota Semarang, UNIMAR AMNI Semarang melaksanaan kegiatan pengabdian masyarakat di kelurahan Trimulyo. Tidak hanya mahasiswa/taruna dan dosen saja yang melaksanakan kegiatan pengabdian masyarakat, tetapi masyarakat sekitar juga sangat antusias dalam ikut serta melaksanakan berbagai program kegiatan yang dilaksanakan di kelurahan Trimulyo. Kegiatan diawali dengan penanaman pohon Mangrove, Sosialisasi hidup sehat di tengah lingkungan yang tidak sehat, Pelatihan memasak dan merapikan lingkungan. Metode pelaksanaan kegiatan yang digunakan adalah metode observasi, wawancara dan studi literatur. Dimana observasi diadakan di kelurahan Trimulyo kecamatan Genuk. Sedangkan pengumpulan data dilaksanakan melalui metode wawancara dengan Masyarakat kelurahan Trimulyo. Dan sebagai dasar acuan pelaksanaan kegiatan pengabdian masyarakat, menggunakan metode studi literatur. Dengan adanya program Gerbang Hebat UNIMAR AMNI Semarang di kelurahan Trimulyo Kecamatan Genuk, diharapkan dapat meningkatkan pola hidup sehat dan peningkatan pendapatan bagi masyarakat kelurahan Trimulyo.
\end{abstract}

Kata kunci : Pemberdayaan masyarakat, Kelurahan Trimulyo, Gerbang Hebat, Pemerintah kota Semarang 


\section{Pendahuluan}

\section{A. Latar Belakang}

Upaya penanggulangan kemiskinan kota Semarang yang merupakan ibukota propinsi Jawa Tengah, terus dilakukan guna menanggulangi lonjakan pengangguran yang mengakibatkan meningkatnya kemiskinan di pedesaan dan perkotaan. Dengan semakin tingginya kebutuhan masyarakat akan pemenuhan kebutuhan hidupnya, menyebabkan masyarakat kota semarang berlombalomba meningkatkan taraf kehidupannya. Sehubungan dengan hal tersebut, dibutuhkan suatu pola baru dalam menangani kemiskinan yang lebih berorientasi pada kemandirian dan berkelanjutan upaya-upaya masyarakat, pemerintah daerah dan kelompok peduli setempat.

Melalui pola baru yaitu Gerbang Hebat (Gerakan Bersama Penanggulangan Kemiskinan dan Pengangguran Melalui Harmonisasi Ekonomi, Edukasi, Ekosistem dan Etos Bersama Masyarakat), diharapkan masyarakat Kota Semarang dapat tumbuh minat dan keinginannya untuk dapat berusaha mandiri/berwiraswasta, sehingga dapat meningkatkan kemampuan sosial ekonominya sesuai dengan tahapan keluarga sejahtera agar lepas dari keterbelakangan sosial ekonomi dan budaya.
Kota Semarang saat ini sedang gencar melakukan pembangunan guna mewujudkan slogan 'Bergerak Bersama Membangun Kota Semarang Menjadi Lebih Baik dan Hebat' baik fisik maupun non fisik. Salah satunya adalah penanggulangan kemiskinan dan pengangguran, peningkatan pelayanan publik, kesetaraan gender serta peningkatan pendidikan dan kesehatan yang tertera dalam sapta program (Pengentasan kemiskinan dan Pengangguran, Penanganan Rob dan Banjir, Peningkatan Infrastruktur, Peningkatan Pelayanan Publik dan Kesetaraan gender)

Pemerintah Kota Semarang memiliki strategi percepatan penanggulangan kemiskinan melalui pendekatan kewilayahan yang bekerjasama dari beberapa unsur. diantaranya kelurahan, kecamatan, Perguruan Tinggi, peran dunia usaha, serta masyarakat itu sendiri melalui program Gerbang Hebat. Program Gerbang Hebat dilakukan di setiap kelurahan dengan memberikan bantuan modal, bantuan barang, serta pelatihan ketrampilan. Selain itu, ada pula program-program penyelamatan, pemberdayaan, dan penguatan yang direalisasikan melalui program bantuan kesehatan, ekonomi, pendidikan, pembangunan infrastruktur, pembangunan 
lingkungan. Diharapkan Perguruan Tinggi Negeri dan Swasta tidak hanya mendukung tapi juga mengerahkan dengan lembaga pengabdian masyarakat sebagai bagian dari Tri Darma Perguruan Tinggi.

\section{Universitas Maritim AMNI} (UNIMAR AMNI) Semarang sebagai mitra kerjasama Pemerintah Kota Semarang melalui Lembaga Penelitian dan Pengabdian Kepada Masyarakat (LPPM) mendapatkan kesempatan untuk mengembangkan dan memberdayakan masyarakat pesisir pantai Kelurahan Trimulyo Kecamatan Genuk. Kegiatan Gerbang Hebat di Kelurahan Trimulyo difokuskan pada Pengembangan lingkungan dengan memperbaikin kondisi pesisir pantai dengan membuat hutan Mangrove, disamping hutan mangrove, kegiatan juga difokuskan untuk memberdayakan masyarakat kelurahan Trimulyo dengan memberikan pelatihan memasak bahan-bahan utama dari bahan dasar ikan yang merupakan ciri khan kelurahan Trimulyo dengan Kampung Tematik hasil olahan ikan. Kegiatan lain yang dilakukan oleh Tim LPPM UNIMAR AMNI Semarang adalah memberikan sosialisasi hidup sehat. Dimana hal ini dilakukan karena kelurahan Trimulyo sering terendam air rob, sehingga kondisi lingkungan menjadi tidak sehat. Dan yang terakhir adalah kegiatan untuk mempercantik lingkungan kelurahan Trimulyo guna menciptakan lingkungan yang bersih dan asri.

Pelaksanaan kegiatan pengabdian masyarakat yang dilaksanakan di kelurahan Trimulyo merupakan jawaban akan kebutuhan masyarakat setempat dalam meningkatkan penghasilan masyarakat yang mayoritas penduduknya adalah nelayan. Ada kalanya hasil tangkapan ikan lebih banyak dari biasanya, dan kadang tidak semua ikan yang dihasilkan laku terjual.Untuk meminimalisasi ikan yang busuk akibat tidak terjual, maka masyarakat Trimulyo membutuhkan pelatihan untuk mengolah ikan-ikan tersebut menjadi bahan yang siap saji. Sehingga ikan tidak terbuang sia-sia karena tidak laku terjual. Hal ini juga dimaksudkan untuk menabah pemasukan bagi warga setempat. Pemberdayaan masyarakat ini, dengan Tema kampung tematik kelurahan Trimulyo yang ditetapkan sebagai kampung olahan hasil ikan oleh Pemerintah Kota Semarang.

\section{B. Perumusan Masalah}

Program

percepatan penanggulangan kemiskinan kota Semarang di kelurahan Trimulyo di fokuskan pada pengembangan lingkungan dengan memperbaiki kondisi pesisir pantai dengan membuat hutan Mangrove, memberikan pelatihan memasak, 
memberikan sosialisasi hidup sehat, mempercantik lingkungan kelurahan Trimulyo guna menciptakan lingkungan yang bersih dan asri. Hal ini dilakukan karena kelurahan Trimulyo merupakan lingkungan di wilayah pesisir pantai dengan masyarakat yang hidup di lingkungan yang tidak sehat, sering terendam air rob, dan mayoritas penduduknya tidak memiliki penghasilan tambahan.

Tujuan dari pemberdayaan masyarakat kelurahan Trimulyo adalah untuk mensukseskan program percepatan penanggulangan kemiskinan di kota semarang untuk tahun 2018. Disamping itu, dengan dipilihnya masyarakat kelurahan Trimulyo, diharapkan penanggulangan kemiskinan dapat tepat sasaran dan bermanfaat bagi masyarakat khususnya masyarakat di kelurahan Trimulyo. Pendampingan di kelurahan tersebut akan terus dilakukan guna mengoptimalkan hasil yang sudah di targetkan.

Manfaat yang diharapkan adalah masyarakat di kelurahan Trimulyo mendapatkan lingkungan yang asri dengan diperbaikinya kondisi pesisir pantai yang tidak terawat dengan baik dengan ditanami hutan Mangrove. Manfaat lain adalah untuk meningkatkan pendapatan tambahan dengan pembekalan pelatihan memasak bagi ibu-ibu masyarakat kelurahan Trimulyo yang tidak memiliki kegiatan selain menjadi ibu rumah tangga. Dengan dilaksanakannya kegiatan pengabdian masyarakat di kelurahan Trimulyo, diharapkan masyarakat mendapatkan manfaat untuk dapat hidup sehat di lingkungan yang tidak sehat. Dimana kelurahan Trimulyo sering terendam air rob, sehingga kondisi lingkungan menjadi tidak sehat.

\section{Metode Pelaksanaan}

Metode pelaksanaan kegiatan yang digunakan adalah metode observasi, wawancara dan studi literatur. Dimana observasi diadakan di kelurahan Trimulyo kecamatan Genuk sesuai dengan ketentuan yang telah ditentukan oleh pemerintah Kota Semarang dalam mensukseskan Gerbang Hebat Kota Semarang. Penunjukan Kelurahan Trimulyo didasarkan kepada Rentra Pengabdian Masyarakat di UNIMAR AMNI yang fokus bergerak untuk mensejahterakan masyarakat di wilayah pesisir pantai. Sedangkan pengumpulan data dilaksanakan melalui metode wawancara dengan Masyarakat kelurahan Trimulyo. Dan sebagai dasar acuan pelaksanaan kegiatan pengabdian masyarakat, menggunakan metode studi literatur.

Berdasarkan metode pelaksanaan 
kegiatan, terdapat beberapa masalah seperti kemiskinan, lingkungan yang tidak kondusif akibat Rob dan minimnya pemahaman masyarakat akan pentingnya pola hidup sehat di lingkungan yang tidak sehat. Untuk itu,Tim Pengabdian Masyarakat telah memberikan beberapa solusi penyeselsaian masalah dengan pengembangan lingkungan, memperbaiki kondisi pesisir pantai dengan membuat hutan Mangrove, memberikan pelatihan memasak, memberikan sosialisasi hidup sehat, mempercantik lingkungan kelurahan Trimulyo guna menciptakan lingkungan yang bersih dan asri. Dalam pelaksanaannya di lapangan kegiatan pengabdian masyarakat didasarkan pada analisis situasi kelompok sasaran (masalah, potensi dan peluang), dimana setelah melaksanakan evaluasi terhadap masyarakat kelurahan Trimulyo, maka langkah selanjutnya adalah mencari solusi baru guna mendapatkan pemecahan masalah. Sementara evaluasi dan alternatif pemecahan masalah akan dilaksanakan setelah wawancara dengan masyarakat kelurahan Trimulyo selesai dilaksanakan.

Di periode waktu tiga bulan setelah pelaksanaan kegiatan pengabdian masyarakat di kelurahan Trimulyo, Tim Pengabdian Masyarakat UNIMAR AMNI melaksanakan observasi guna mengukur tingkat pelaksanaan program yang telah dilaksanakan. Untuk penanaman pohon Mangrove yang rudak akibat terkena ombak, maka tim pelaksana kegiatan bersama masyarakat menanam kembali pohon yang surak. Sedangkan untuk olahan hasil ikan, tim pengabdian akan meninjau keberhasilan masyarakat Trimulyo dalam mengolah hasil tangkapan ikan menjadi produk jadi, jika ternyata berkembang dengan baik, maka tim akan mengagendakan kegiatan selanjutnya untuk meningkatkan ketrampilan dalam mengolah hasil ikan dan juga meningkatkan masyarakat dalam ketrampilan memasarkan produknya. Dan untuk kebersihan lingkungan, Timdapat berkoordinasi dengan masyarakat setempat untuk terus berupaya menyadarkan masyarakat akan penringnya kebersihan lingkungan guna kesehatan bersama.

\section{Pembahasan}

Pelaksanaan kegiatan pengabdian masyarakat di kelurahan Trimulyo dilaksanakan dalam beberapa pentahapan. Dimana tahap yang pertama adalah melaksanakan observasi guna menyesuaikan antara program yang telah disusun dengan kebutuhan masyarakat yang ada di kelurahan Trimulyo, Tahap yang ke dua adalah wawancara dengan masyarakat sekitar, diharapkan dengan wawancara ini, apa yang diharapkan oleh 
masyarakat dalam terealisasi oleh kegiatan pengabdian masyarakat, dan tahap yang terakhir adalah langsung terjun ke lapangan guna melaksanakan program kegiatan yang telah direncanakan dan disesuaikan dengan kebvutuhan masyarakat.

Tahapan pelaksanaan disesuaikan dengan kondisi yang ada di lingkungan kelurahan Trimulyo. Keterlibatan masyarakat dalam pelaksanaan pengabdian masyarakat sangat baik. Disamping masyarakat kelurahan Trimulyo, mahasiswa/taruna beserta dosen UNIMAR AMNI Semarang juga bersama-sama melaksanakan kegiatan pengabdian masyarakat. Dalam pelaksanaannya, kegiatan pengabdian masyarakat di kelurahan Trimulyo diawali dengan penanaman pohon Mangrove, Sosialisasi hidup sehat di tengah lingkungan yang tidak sehat, Pelatihan memasak dan merapikan lingkungan.

\section{A. Penanaman Pohon Mangrove}

Kelurahan Trimulyo kecamatan Genuk berada di daerah pesisir pantai yang gersang. Namun, perhatian masyarakat di lingkungan kelurahan Trimulyo sangat tinggi terhadap lingkungannya. Cita-cita untuk membuat lingkungan pesisir pantai menjadi teduh dan indah sangatlah tinggi. Untuk itu, tim Pengabdian Masyarakat UNIMAR AMNI Semarang berupaya untuk mewujudkan cita-cita masyarakat pesisir pantai kelurahan Trimulyo dengan mengadakan penanaman pohon mangrove di sekitar pesisir pantai kelurahan Trimulyo.

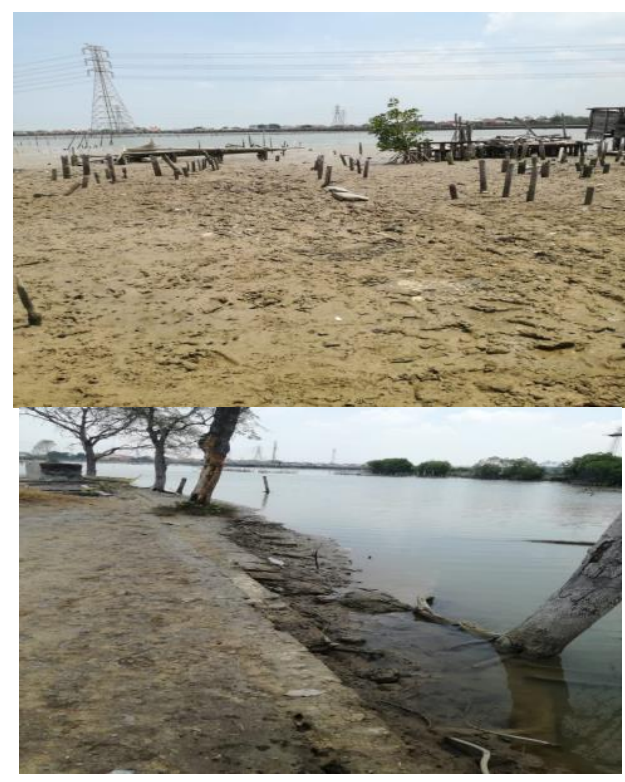

Gambar 1. Kondisi daerah pesisir pantai Kelurahan Trimulyo

Dalam pelaksanaan kegiatan untuk penanaman pohon mangrove di pesisir pantai kelurahan Trimulyo, Tim pelaksana kegiatan UNIMAR AMNI Semarang bekerjasama dengan Pangkalan TNI Angkatan Laut (LANAL) Semarang. Bersama-sama dengan LANAL Semarang, Tim pelaksana kegiatan pengabdian masyarakat UNIMAR AMNI Semarang menghijaukan daerah pesisir pantai. 


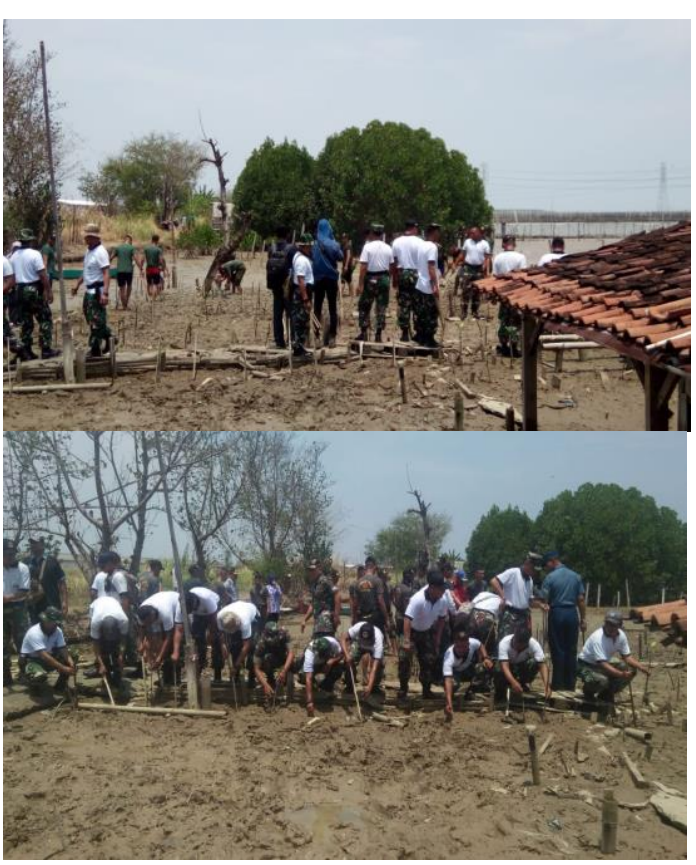

Gambar 2. UNIMAR AMNI Semarang bersama LANAL Semarang melaksanakan kegiatan penanaman pohon mangrove

Tim Pelaksana kegiatan pengabdian masyarakat UNIMAR AMNI Semarang tidak hanya terdiri dari dosen saja, tetapi juga melibatkan taruna/taruni yang berjumlah sekitar 40 orang. Untuk kegiatan penanaman pohon Mangrove, kegiatan dilaksanakan dalam waktu 3 hari berturutturut. Hari pertama pelaksanaan kegiatan penanaman pohon mangrove dilaksanakan dengan kegiatan survey dan bersih-bersih area penanaman pohon mangrove.

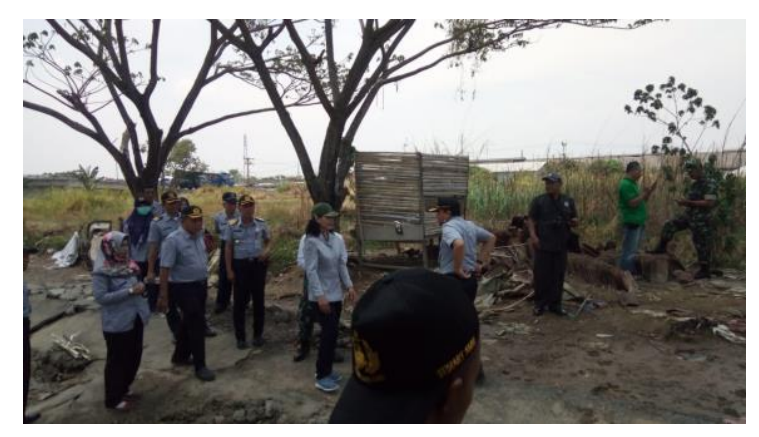

Gambar 3. Kegiatan survey penanaman pohon Mangruve

Hari kedua pelaksanaan kegiatan penanaman pohon mangrove dilaksanakan dengan menanam 500 bibit pohon mangrove. Penanaman pohon disesuaikan dengan kondisi pesisir pantai. Saat air surut, penanaman baru dapat dilaksanakan oleh tim pelaksana kegiatan pengabdian masyarakat. Hari ketiga pelaksanaan kegiatan penanaman pohon mangrove dilaksanakan dengan menanam kembali pohon mangrove, baik pohon baru di sisi pesisir yang berbeda, maupun pohon yang telah ditanam sebelumnya yang kondisinya rusak akibat hantaman ombak.

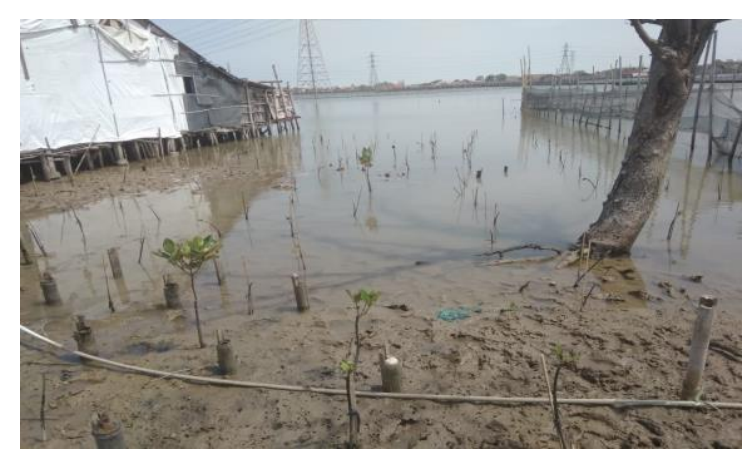

Gambar 4. Kondisi pohon mangrove setelah ditanam 


\section{B. Sosialisasi Hidup Sehat}

Kondisi lingkungan kelurahan Trimulyo sangatlah tidak sehat, kelurahan Trimulyo sering tergenang air Rob. Pada saat musim hujan, kondisi kelurahan Trimulyo semakin parah, hampir setiap hari, lingkungan perkampungan yang ada di kelurahan Trimulyo selalu tergenang oleh air Rob.

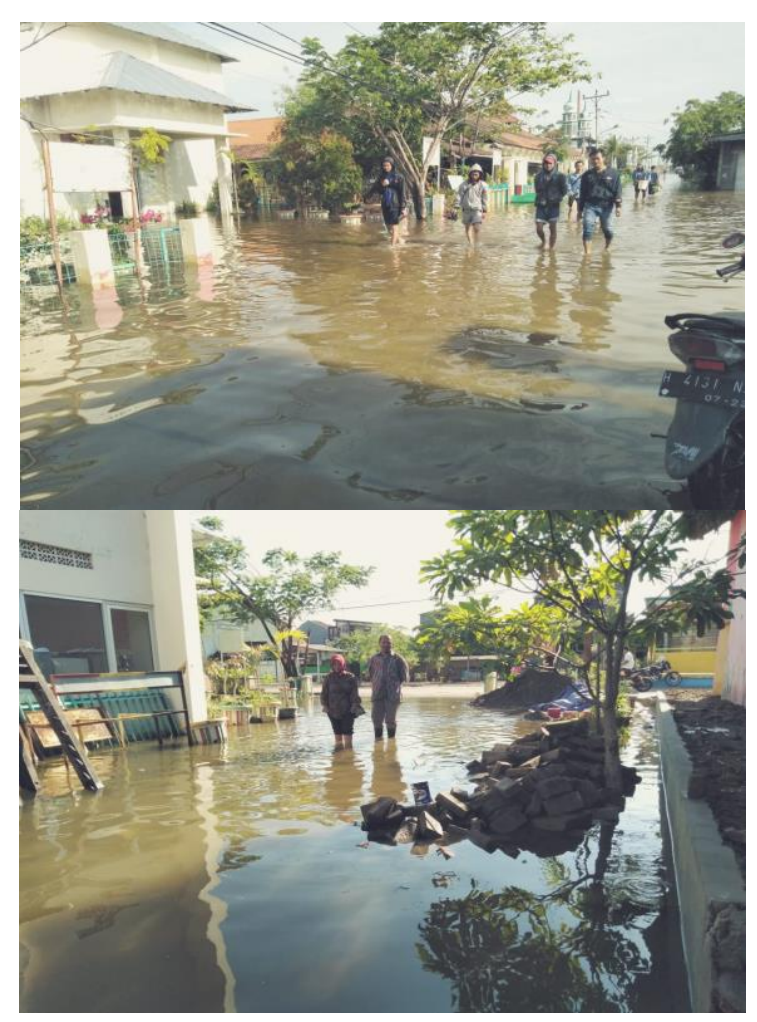

Gambar 5. Lingkungan kelurahan

Trimulyo saat rob

Untuk itu, tim pelaksana kegiatan UNIMAR AMNI Semarang berupaya untuk memberikan sosialisasi kepada masyarakat kelurahan Trimulyo untuk dapat hidup sehat di lingkungan yang tidak sehat.

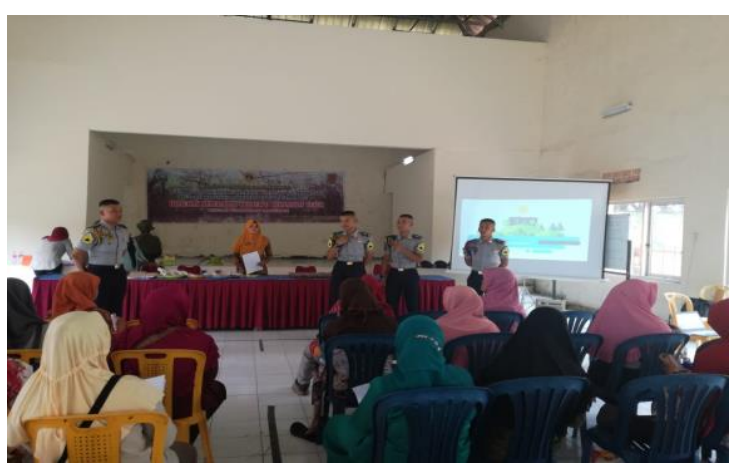

Gambar 6. Taruna sedang memberikan sosialisasi Hidup Sehat di Lingkungan yang Tidak Sehat

\section{Pelatihan Memasak}

Pemerintah kota Semarang melalui program Gerbang Hebat (Gerakan Bersama Penanggulangan Kemiskinan dan Pengangguran Melalui Harmonisasi Ekonomi, Edukasi, Ekosistem dan Etos Bersama Masyarakat), mengharapkan masyarakat Kota Semarang dapat hidup lehih sejahtera dengan memiliki usaha mandiri. Untuk itu tim pelaksana kegiatan pengabdian UNIMAR AMNI Semarang memiliki program peningkatan pendapatan masyarakat kelurahan Trimulyo, melalui pelatihan memasak dari bahan olahan ikan. Hal ini disesuaikan dengan tema kelurahan Trimulyo yang merupakan Kampung Olahan hasil Ikan. 


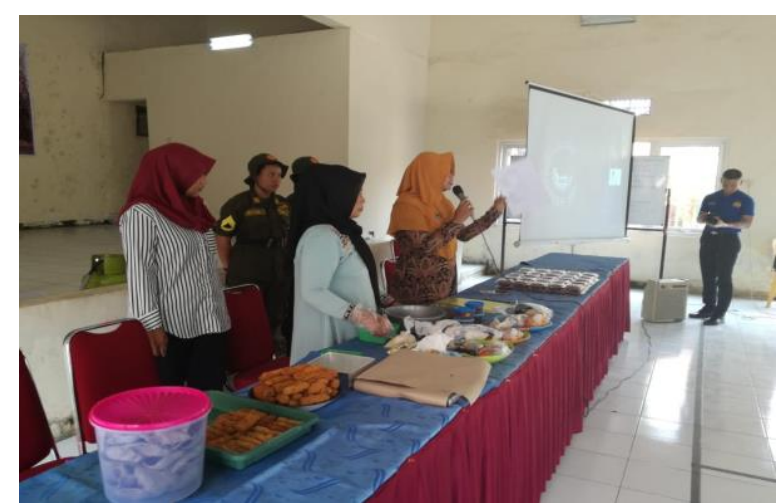

Gambar 7. Pelatihan mengolah bahan dasar ikan menjadi bahan siap saji

Berbagai macam masakan olahan hasil ikan telah diberikan untuk menjadi alternatif pendapatan tambahan masyarakat kelurahan Trimulyo. Dengan memasak, masyarakat dapat mengolah hasil ikan dari para nelayan yang kadang hasil tangkapannya lebih banyak dari hari biasa. Dengan keahlian memasak dengan bahan dasar ikan, diharapkan masyarakat kelurahan Trimulyo dapat mandiri dan menjadi masyarakat yang mahir dalam mengolah ikan.

\section{Merapikan Lingkungan}

Dalam rangka menutup serangkaian kegiatan pengabdian masyarakat yang di selenggarakan di kelurahan Trimulyo kecamatan Genuk, tim pelaksanakan kegiatan pengabdian masyarakat UNIMAR AMNI Semarang mengadakan kegiatan bersih-bersih lingkungan. Hal ini merupakan serangkaian kegiatan dalam hal UNIMAR AMNI Semarang peduli kebersihan. Semua Tim baik itu dosen maupun taruna, ikut serta dengan masyarakat kelurahan Trimulyo untuk membersihkan lingkungan.

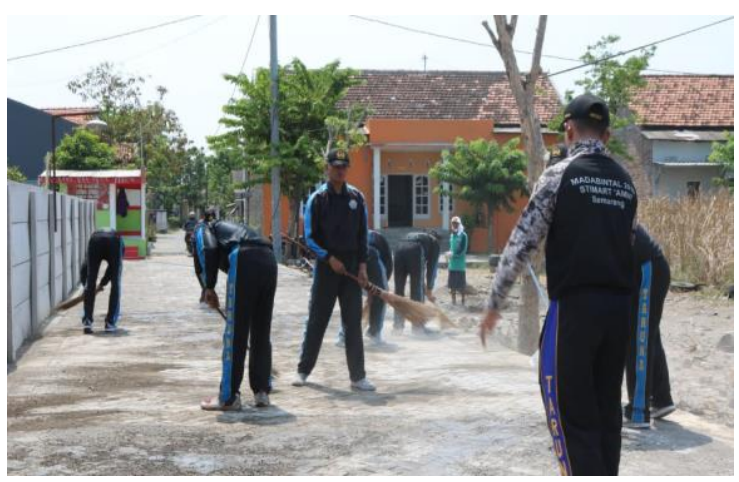

Gambar 8. Taruna dan Masyarakat

\section{bersih-bersih lingkungan}

Tidak hanya kebersihan lingkungan saja yang dilakukan oleh tim pengabdian masyarakat, tetapi juga menghijaukan lingkungan masyarakat di kelurahan Trimulyo dengan memberikan tanaman hias untuk di tanam disekitar rumah. Dan untuk kebersihan lingkungan agar tetap terjaga dengan baik, maka tim pelaksana kegiatan pengabdian masyarakat juga memberikan tong sampah kepada masyarakat di sekitar kelurahan Trimulyo.

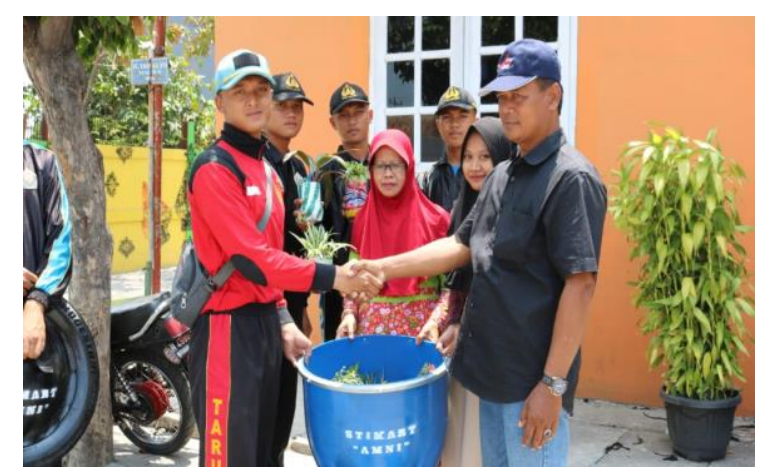

Gambar 9. Pemberian tempah sampah dan tanaman hias 
Dan untuk mempercantik salah satu gapura yang ada di salah satu RT (Rukun Tetangga) yang ada di kelurahan Trimulyo, tim pelaksana kegiatan pengabdian masyarakat UNIMAR AMNI Semarang mempercantik Gapura. Dimana gapura tersebut kondisi sebelumnya sangat tidak layak dan lama tidak terurus. Dan dengan kegiatan pengabdian masyarakat UNIMAR AMNI Semarang, gapura dibuat dengan asas gotong rotong antara warga dengan civitas akademika UNIMAR AMNI Semarang. Diharapkan dengan gapura tersut, Kelurahan Trimulyo semakin terlihat bersih, rapi dan tertata dengan baik.

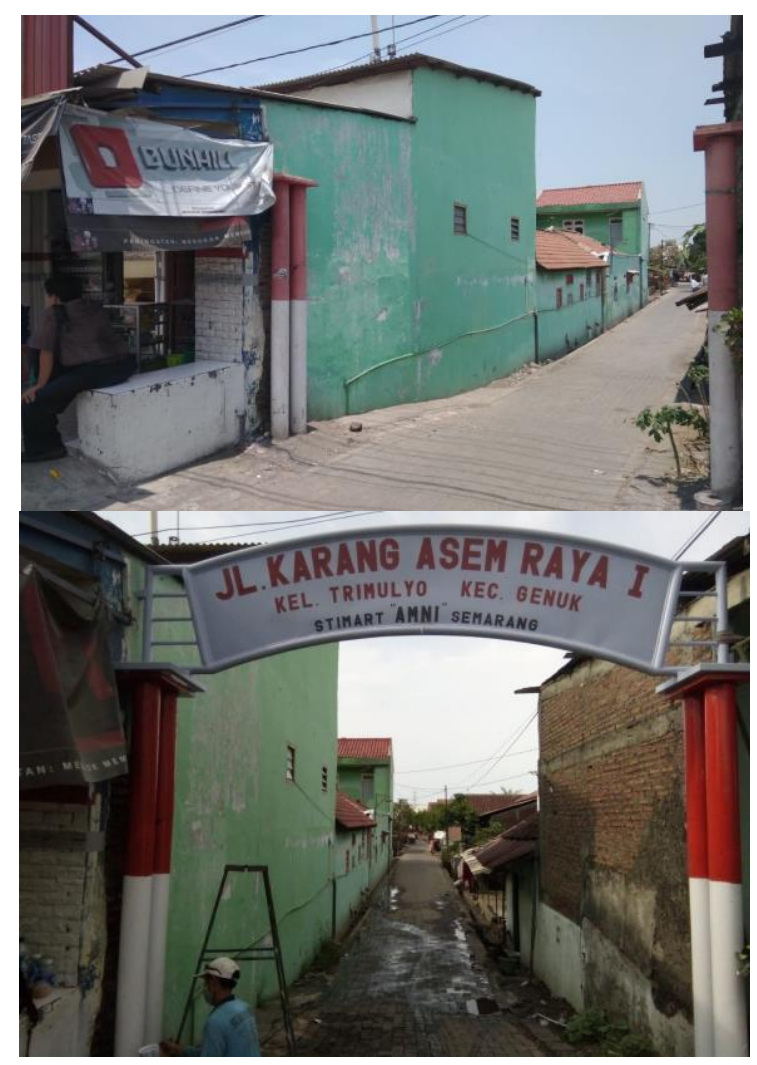

Gambar 10. Gapura setelah pemasangan dan sebelum pemasangan

\section{E. Evaluasi Pelaksanaan Kegiatan}

Pelaksanaan kegiatan pengabdian masyarakat dalam mensukseskan program pemerintah Gerbang Hebat di kelurahan Trimulyo, berjalan dengan lancar dan mendapatkan dukungan yang luar biasa dari perangkat kelurahan, masyarakat setempat maupun pemerintah daerah. Dimana pola hidup masyarakat menjadi lebih peduli terhadap lingkungannya, masyarakat kelurahan Trimulyo memiliki kesibukan yang menghasilkan pendapatan sampingan berupa pengolahan hasil ikan menjadi produk yang siap saji. Dan dengan bantuan berupa alat-alat kebersihan dan tanaman hias, membuat masyarakat Kelurahan Trimulyomenjadi lebih kreatif dengan memodifikasi alat kebersihan menjadi lebih indah danmenyusunnya rapi di setiap halaman rumah. Sedangkan Hutan mangrove menjadikan masyarakat kelurahan Trimulyo berharapbisa menjadi daerah wisata hutan mangrove kedepannya.

\section{Penutup}

Dengan adanya program Gerbang Hebat UNIMAR AMNI Semarang di kelurahan Trimulyo Kecamatan Genuk, diharapkan dapat meningkatkan pola hidup sehat dalam masyarakat dan kepedulian masyarakat dalam menghijaukan pesisir pantai yang selama ini sudah berkembang 
dengan baik di kelurahan Trimulyo.

Kemandirian dengan menghasilkan pendapatan tambahan melalui hasil olahan ikan yang merupakan temantik dari masyarakat kelurahan Trimulyo diharapkan dapat meningkatkan taraf hidup masyarakatnya. Peran aktif dari masyarakat di kelurahan Trimulyo untuk merawat sarana dan prasarana baik itu hutan mangrove, gapura, penanaman tanaman hias di sekitar rumah, sangat diharapkan guna menjaga lingkungan hijau yang bersih dan asri, dapat dimanfaat dengan baik dalam jangka waktu yang memadai. Dengan peran aktif masyarakat kelurahan Trimulyo, kegiatan pelaksanaan pengabdian masyarakat di Kelurahan Trimulyo dapat berjalan dengan baik dan lancar.

\section{DAFTAR PUSTAKA}

[1] Kusmuljono BS, Ketua Tim Koordinasi Keuangan Mikro Indonesia, UKM : Menggerakkan yang kecil, mengentaskan kemiskinan, Gatra, 2 Januari 2008.

[2] Nofia Farida, 2010, Obyek Wisata Pantai Tirto Samudra berpotensi meningkatkan Kehidupan Sosial Ekonomi Masyarakat

[3] Sanim, B., 2009, Usaha Kecil, Menengah dan Koperasi dalam
Mewujudkan Sistem Ekonomi Kerakyatan Menanggulangi Krisis Nasional. MMA-IPB. Bogor.

[4] Wahab Saleh, 2009. Managemen Pariwisata. Jakarta, Pradya Paramita 